\title{
An Analysis of User Satisfaction of K University’s Library Service
}

\author{
Younghee Noh*, \\ Min-Ju Choi**, Yong-Wog Choi**, Sin-Won Jeong**, Eun-Ji Jung**, \\ Mi-So Kang**, Jin-Young Kim**, Kyung-Won Lee**, Sung-Jae Lee**, \\ Seon-Hye Oh**, So-Yeon Park**, Sung-Chul Shin**, Da-Jeong Suh**
}

\section{ARTICLE INFO}

Article history:

Received 4 April 2011

Revised 22 May 2011

Accepted 10 June 2011

Keywords:

Academic Library,

User Satisfaction,

Information Service,

User Survey

\begin{abstract}
This study purposed to discover whether or not academic libraries reflect these changing roles. We selected $\mathrm{K}$ University as the research target and surveyed user satisfaction of materials, staff services, facilities, electronic devices, media, and so on.

The research findings are as follows: 1) the frequency of library visits of University $\mathrm{K}$ was on the high side, 2) the primary purpose of using the academic library was associated with learning or reading, therefore, the most used library spaces were related to that, 3) the most used library materials were 'general books', the most unused were 'reference books', 4) the most preferred way to obtain needed materials when failing to find wanted materials was 'Contact librarian'. A similar phenomenon occurred in terms of facility use, 5) university K's users were usually satisfied with the loan policy, 6) the rate of users who don't know whether there is user education was very high, the rate of users who have no experience with user education was extremely low. These research findings can be referenced by library management to improve libraries' service quality and take advantage of complex spatial configurations.
\end{abstract}

\section{Introduction}

University libraries and college education are closely linked. The information society increases the competitive power of the university and the academic library, which strengthens national competitive power. So the academic library must be operated developmentally for both academic and national competitiveness. To support professors and students in their research and learning activities, appropriate facilities and systems must be equipped with features, and the role of university libraries will be properly fulfilled.

Libraries are one of the central organizations to support the functions of the university. Academic libraries provide information resources that their members need. The role of providing information resources will have a huge impact on the development of universities' education and scientific research

* Professor of Library \& Information Science, Konkuk University (irs4u@kku.ac.kr)

** Library \& Information Science, Konkuk University International Journal of Knowledge Content Development \& Technology, 1(1): 61-79, 2011. [http://dx.doi.org/10.5865/IJKCT.2011.1.1.061] 
(Noh, 2011).

Academic libraries collect, organize and archive their members' needed information resources, and try to provide them effectively. Recently, due to advancing computer systems and high-speed networks, academic libraries have been required to change their system operations (Back, 2001). They are transforming into complex spaces for communication, relaxation, and information commons to reflect their increased users' needs.

Korean academic libraries introduced an online search system since the 20th century. After that, they were equipped with library automation systems for the convenience of librarians and patrons. Since then, they have been continually strived to reflect environmental changes to their libraries and meet users' needs in terms of building, remodeling, information resources, facilities, and services.

This study purposed to discover whether or not academic libraries are actually reflecting these changing roles, selected $\mathrm{K}$ University as the research target and surveyed user satisfaction there.

\section{Related studies}

There is much research about university libraries, some especially focused on user satisfaction. In this section, we analyzed the studies related to user satisfaction in academic libraries. Back (2001) studied the operating plan for a customer-oriented library, and reported that areas with the highest satisfaction were the promptness of circulation, followed by processing fines, the library's location. The areas of lowest satisfaction were users' complaint processing speed and marketing method. Based on his study, he recommended that the library could improve the user satisfaction by raising the likelihood of finding their needed materials on the shelves and securing learning facilities. He also suggested that continuing interest in better information services is needed because user satisfaction may vary depending on situational factors.

Yoo (2005) purposed to identify user satisfaction for an academic library in order to investigate problems in academic library management and to create library development strategies. This study also includes relative functions between academic education and academic libraries. The research method for this study is a survey for undergraduate students in K University. Results of the survey can be regarded as users' needs, and can be used for fundamental data and an assessment measure in order to develop an academic library operation plan.

Nam and Moon (2009) studied user satisfaction in spatial composition before and after the remodeling of a university library, focusing on $\mathrm{C}$ university library. In this study, they analyzed changes in the configuration of space, and surveyed for user satisfaction before and after the remodel. Then the results were analyzed based on C University Library. As a result of this study, the library remodel was utilized to determine the importance of library space in the future; these results increase the quality of library service or library user satisfactions.

Nam and Choi (2011) focused on user satisfaction with e-Book services in university libraries. This research surveyed college students in Korea on their satisfaction with e-book services provided by university libraries. Their usage behavior was investigated, and the satisfaction rate for e-book usage and its service quality were analyzed to determine the status of e-book usage. The analysis 
showed that overall satisfaction for e-book service of university libraries was $2.93 \%$ on average. Moreover, the more frequently a student used the service, the more satisfied the student was: junior/senior-level and graduate school student groups showed higher satisfaction for e-book service than freshman and sophomore students. The most influential factor for satisfaction based on the e-book service quality was the content of the service, followed by the library support service system. Based on the findings, reinforcement of library public relations and user education, and maintenance of the variety and up-to-date status of the contents were proposed to stimulate future university library e-book services.

Kim (2008) studied the user satisfaction and loyalty of university library users. The research purpose for this paper is an adopted version of the European Customer Satisfaction Index (ECSI) in a survey performed on library users to measure user satisfaction and loyalty factors. A questionnaire was designed to integrate measurement into the library's management system for visual analysis of what users expect from the library. Results from the survey showed that users expect more improvement in the library environment and collection of printed publications. Concluding from the survey, Kim made the following suggestions to satisfy user expectations: 1) improve library environment, 2) increase collections of printed publications and periodical to meet readers' demands, 3) offer more friendly and helpful user service.

The above studies mainly evaluated the general and common factors including collection, buildings, space, and so on. But modern academic libraries are improving to 'Information Commons' space, a complex space accompanying the community and the rest, and a space providing e-services. Therefore, studies surveying all activities and all library components rather than user satisfaction with the materials should be conducted. This study surveyed and investigated the complex factors including facilities, services, environment, and so on, and user satisfaction of them overall.

\section{Research design and methodology}

\subsection{Data collection}

To perform this study, the researchers targeted undergraduates of university K, distributing 800 questionnaires, which is equivalent to 10 percent of all students of university $\mathrm{K}$, who can be users of central library. We directly distributed the questionnaire and surveyed the extracted sample respondents. The questionnaire cover letter included the purpose of the research and survey, and also a simple statement informing them that they are the extracted samples. Afterwards, respondents had an understanding of the survey through the cover letter, and then participated in the survey voluntarily. As a result, the number of collected questionnaires from the total distributed 800 was 184, the response rate was 23\%. The survey period was from May 1 through 30, 2011.

Answered and returned questionnaires were coded for each question. The primary coded data was contrasted with the original questionnaires for accuracy once again. Through a review process, primary coded data and secondary reviewed data were completed. For statistical analysis, statistical package SPSS (PASW Statistics 18) was used. For each question of the survey, frequency analysis and descriptive statistics were calculated. 


\subsection{Configuration of survey questions}

The survey questions are composed of 5 sections and 21 questions. The 5 sections are about respondents' demographic information, users' library using patterns, user satisfaction, the libraries' functionality, user training, and other comments. Contents and configuration of the questionnaire are as follows in Table 1 .

Table 1. Items and configuration of the questionnaire

\begin{tabular}{|c|c|c|c|}
\hline Survey area & Detailed survey area & Surveyed contents & $\begin{array}{l}\text { Question } \\
\text { Number }\end{array}$ \\
\hline \multirow[t]{6}{*}{ Library Usage } & \multirow[t]{4}{*}{ Library usage } & Library using frequency & 4 \\
\hline & & The main purpose for using the library & 5 \\
\hline & & The materials commonly used in the library & 6 \\
\hline & & The space most used in the library & 7 \\
\hline & Troubleshooting & How to troubleshoot from the library materials & 8 \\
\hline & & How to troubleshoot from the library facilities & 9 \\
\hline \multirow{12}{*}{$\begin{array}{l}\text { Library using } \\
\text { satisfaction } \\
\text { and the needs } \\
\text { of user } \\
\text { training }\end{array}$} & \multirow{7}{*}{$\begin{array}{l}\text { User satisfaction and } \\
\text { requirements }\end{array}$} & Loan Period & 10 \\
\hline & & The number of loaned books & 11 \\
\hline & & Library Services & 12 \\
\hline & & Timeliness of library materials & 13 \\
\hline & & Variety of library materials & 14 \\
\hline & & Library Facilities and Environments & 15 \\
\hline & & Requirements for new space & 16 \\
\hline & \multirow[t]{5}{*}{ needs of user training } & Aware of the presence of user education & 17 \\
\hline & & Whether or not educational experience & 18 \\
\hline & & Number of trainings received & 19 \\
\hline & & Satisfaction with user training & 20 \\
\hline & & Needs for user training in the library & 21 \\
\hline \multirow{3}{*}{$\begin{array}{l}\text { Demographic } \\
\text { information }\end{array}$} & Gender & & 1 \\
\hline & Year & & 2 \\
\hline & School of Study & & 3 \\
\hline
\end{tabular}

\section{Results}

\subsection{Demographic Information}

In this part, we presented the gender, year, and school of study of $\mathrm{K}$ university library's users. The following Table 3 is about year by gender. Comparing the gender of respondents, the number of male respondents was 72 to 112 female respondents, meaning female respondents were higher than men by approximately $20 \%$. The distribution of year ranges from $17.4 \%$ (Year 2) to $33.7 \%$ (Year 4); it can be said the number of respondents by year are distributed evenly. 
Y. H. Noh et al.

Table 2. Year by Gender

\begin{tabular}{|c|c|c|c|c|c|c|c|}
\hline & & & \multicolumn{4}{|c|}{ Year in University } & \multirow[t]{2}{*}{ All } \\
\hline & & & Year 1 & Year 2 & Year 3 & Year 4 & \\
\hline \multirow[t]{4}{*}{ Gender } & Male & freq. & 17 & 16 & 18 & 21 & 72 \\
\hline & & $\%$ & $9.2 \%$ & $8.7 \%$ & $9.8 \%$ & $11.4 \%$ & $39.1 \%$ \\
\hline & Female & freq. & 27 & 16 & 28 & 41 & 112 \\
\hline & & $\%$ & $14.7 \%$ & $8.7 \%$ & $15.2 \%$ & $22.3 \%$ & $60.9 \%$ \\
\hline \multirow[t]{2}{*}{ All } & & freq. & 44 & 32 & 46 & 62 & 184 \\
\hline & & $\%$ & $23.9 \%$ & $17.4 \%$ & $25.0 \%$ & $33.7 \%$ & $100.0 \%$ \\
\hline
\end{tabular}

The following Table 3 shows the distribution of respondents by colleges. K University's six colleges were surveyed for this study. When comparing the number of respondents by colleges, College of Humanities was the highest with 39.7\%, and College of Global Studies was the lowest with $6.5 \%$. When separated by gender, female respondents in college of Humanities were examined most with 51 respondents $(27.7 \%)$.

Table 3. College by Gender

\begin{tabular}{|c|c|c|c|c|c|c|c|c|c|}
\hline & & & \multicolumn{6}{|l|}{ College } & \multirow[t]{2}{*}{ All } \\
\hline & & & Humanities & $\begin{array}{l}\text { Social } \\
\text { Sciences }\end{array}$ & $\begin{array}{l}\text { Natural } \\
\text { Sciences }\end{array}$ & $\begin{array}{l}\text { Art \& } \\
\text { Design }\end{array}$ & $\begin{array}{l}\text { Biomedical } \\
\& \text { Health } \\
\text { Science }\end{array}$ & $\begin{array}{l}\text { College of } \\
\text { Global } \\
\text { Studies }\end{array}$ & \\
\hline \multirow[t]{4}{*}{ Gender } & Male & freq. & 22 & 20 & 16 & 1 & 8 & 5 & 72 \\
\hline & & $\%$ & $12.0 \%$ & $10.9 \%$ & $8.7 \%$ & $.5 \%$ & $4.3 \%$ & $2.7 \%$ & $39.1 \%$ \\
\hline & Female & freq. & 51 & 17 & 12 & 13 & 12 & 7 & 112 \\
\hline & & $\%$ & $27.7 \%$ & $9.2 \%$ & $6.5 \%$ & $7.1 \%$ & $6.5 \%$ & $3.8 \%$ & $60.9 \%$ \\
\hline \multirow[t]{2}{*}{ All } & & freq. & 73 & 37 & 28 & 14 & 20 & 12 & 184 \\
\hline & & $\%$ & $39.7 \%$ & $20.1 \%$ & $15.2 \%$ & $7.6 \%$ & $10.9 \%$ & $6.5 \%$ & $100.0 \%$ \\
\hline
\end{tabular}

The following Table 4 is the correlation table between Year and Colleges. The college and year showing the highest response rate were $4^{\text {th }}$ Year in college of Humanities, followed by the $3^{\text {rd }}$ Year in the same college. College of Art \& Design showed the lowest response rate.

Table 4. Correlation table of years and college

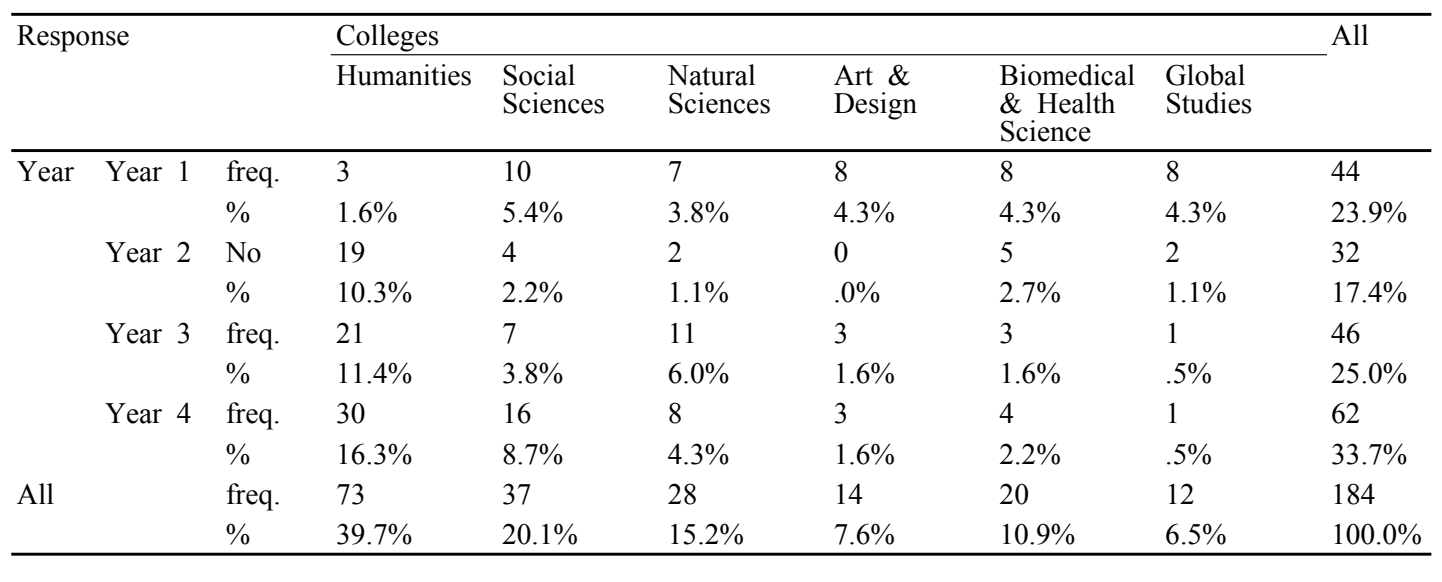




\subsection{Frequency of library visit}

The following Table 5 is about the frequency which $\mathrm{K}$ University users visit and use the central library. The question asking about their library visit frequency was composed of 5 possible responses: 1-3 times a week, 4 or more times a week, 1-3 times a month, 1-3 times in one semester, and never use. The 'never use' response was zero, so four responses were analyzed.

In analysis of 'frequency of library visits', '1-3 times a week' is the most frequently chosen, '1-3 times in one semester' was the least. Overall, it can be said that the frequency of library visits were on the high side.

When analyzing 'frequency of library visit' by gender, the number of respondents answering that they use the library in ' $1-3$ times a week', was the highest with $50.5 \%$ (93 respondents). It was followed by 'more than 4 times a week' with 41 respondents ( 22.3 percent), '1-3 times per month' with $40(21.7 \%)$, ' $1-3$ times in one semester' with 10 people (5.4 percent). Overall, female users $(60.9 \%)$ visited the library more frequently compared to male with $3.91 \%$. Especially, the female response rate answering '1-3 times a week' was the highest.

When analyzing by year, the highest number of respondents was $4^{\text {th }}$ year (62 respondents, 33.7\%), followed by $3^{\text {rd }}$ year $(25.8 \%), 1^{\text {st }}$ year $(23.9 \%)$, and $2^{\text {nd }}$ year $(25.0 \%)$. And In the cross-analysis of year and frequency of visits, the highest point is the 4th year responding '1-3 times a week' (35 respondents, $19.0 \%$ ).

When analyzing the frequency of library visits by colleges, the college of Humanities recording $39.7 \%$ (73 respondents) showed the highest, followed by college of Social Science with $20.1 \%$ (37), college of Natural Science with 15.2\% (28). College of Global Studies showed the lowest visit rate. In the cross-analysis of colleges and frequency of visits, the highest point is the college of Humanities responding '1-3 times a week' (35 respondents, 19.0\%).

Table 5. Frequency of library visit

\begin{tabular}{|c|c|c|c|c|c|c|c|}
\hline & & & \multicolumn{4}{|c|}{ Frequency of library visit } & \multirow[t]{2}{*}{ All } \\
\hline & & & $\begin{array}{l}1-3 \text { times a } \\
\text { week }\end{array}$ & $\begin{array}{l}4 \text { or more times } \\
\text { a week }\end{array}$ & $\begin{array}{l}1-3 \text { times a } \\
\text { month }\end{array}$ & $\begin{array}{l}1-3 \text { times in } \\
\text { one semester }\end{array}$ & \\
\hline \multirow[t]{4}{*}{ Gender } & Male & freq. & 33 & 21 & 14 & 4 & 72 \\
\hline & & $\%$ & $17.9 \%$ & $11.4 \%$ & $7.6 \%$ & $2.2 \%$ & $39.1 \%$ \\
\hline & Female & freq. & 60 & 20 & 26 & 6 & 112 \\
\hline & & $\%$ & $32.6 \%$ & $10.9 \%$ & $14.1 \%$ & $3.3 \%$ & $60.9 \%$ \\
\hline \multirow[t]{8}{*}{ Year } & Year 1 & freq. & 25 & 8 & 10 & 1 & 44 \\
\hline & & $\%$ & $13.6 \%$ & $4.3 \%$ & $5.4 \%$ & $.5 \%$ & $23.9 \%$ \\
\hline & Year 2 & freq. & 13 & 6 & 12 & 1 & 32 \\
\hline & & $\%$ & $7.1 \%$ & $3.3 \%$ & $6.5 \%$ & $.5 \%$ & $17.4 \%$ \\
\hline & Year 3 & freq. & 20 & 14 & 8 & 4 & 46 \\
\hline & & $\%$ & $10.9 \%$ & $7.6 \%$ & $4.3 \%$ & $2.2 \%$ & $25.0 \%$ \\
\hline & Year 4 & freq. & 35 & 13 & 10 & 4 & 62 \\
\hline & & $\%$ & $19.0 \%$ & $7.1 \%$ & $5.4 \%$ & $2.2 \%$ & $33.7 \%$ \\
\hline \multirow[t]{2}{*}{ Colleges } & Humanities & freq. & 35 & 19 & 16 & 3 & 73 \\
\hline & & $\%$ & $19.0 \%$ & $10.3 \%$ & $8.7 \%$ & $1.6 \%$ & $39.7 \%$ \\
\hline
\end{tabular}


Y. H. Noh et al.
International Journal of Knowledge Content Development \& Technology Vol.1, No.1, 61-79 (June, 2011)

\begin{tabular}{|c|c|c|c|c|c|c|c|}
\hline & & & Frequency o & ibrary visit & & & All \\
\hline & & & $\begin{array}{l}1-3 \text { times a } \\
\text { week }\end{array}$ & $\begin{array}{ll}4 \text { or more times } & 1 \\
\text { a } \text { week } & n\end{array}$ & $\begin{array}{l}1-3 \text { times a } \\
\text { month }\end{array}$ & $\begin{array}{l}1-3 \text { times in } \\
\text { one semester }\end{array}$ & \\
\hline & Social Science & freq. & 21 & 6 & 9 & 1 & 37 \\
\hline & & $\%$ & $11.4 \%$ & $3.3 \%$ & $4.9 \%$ & $.5 \%$ & $20.1 \%$ \\
\hline & Natural Sciences & freq. & 14 & 4 & 7 & 3 & 28 \\
\hline & & $\%$ & $7.6 \%$ & $2.2 \%$ & $3.8 \%$ & $1.6 \%$ & $15.2 \%$ \\
\hline & Art \& Design & freq. & 5 & 2 & 6 & 1 & 14 \\
\hline & & $\%$ & $2.7 \%$ & $1.1 \%$ & $3.3 \%$ & $.5 \%$ & $7.6 \%$ \\
\hline & Biomedical \& & freq. & 10 & 7 & 1 & 2 & 20 \\
\hline & Health Science & $\%$ & $5.4 \%$ & $3.8 \%$ & $.5 \%$ & $1.1 \%$ & $10.9 \%$ \\
\hline & Global Studies & freq. & 8 & 3 & 1 & 0 & 12 \\
\hline & & $\%$ & $4.3 \%$ & $1.6 \%$ & $.5 \%$ & $.0 \%$ & $6.5 \%$ \\
\hline All & & freq. & 93 & 41 & 40 & 10 & 184 \\
\hline & & $\%$ & $50.5 \%$ & $22.3 \%$ & $21.7 \%$ & $5.4 \%$ & $100.0 \%$ \\
\hline
\end{tabular}

\subsection{The purpose of using the library}

The users' purpose in using the library was surveyed, allowing them to choose three of the many possible responses. As a result, the total number of responses was 436 . The results are summarized in Table 6.

The primary purpose of using the academic library was circulation (31.9\%), followed by study subjects, homework (17.7\%), class (lecture) preparation (11.5\%), and reading books/journal/magazines $(10.1 \%)$. All of the above purposes are items associated with learning or reading, therefore it can be said that users' library using purposes are related to learning and reading. On the other hand, the rate of respondents who visit the library to meet friends or to make use of facilities, or for leisure, was very low (about 5\%).

Table 6. The purpose of using the library

\begin{tabular}{lll}
\hline Library use purpose & Respondents & Percent \\
\hline Circulations & 139 & 31.9 \\
For reading books/journal/magazines & 44 & 10.1 \\
Reference service from Librarians & 1 & 0.2 \\
Class (lecture) Preparation & 50 & 11.5 \\
Data collection for research & 3 & 0.7 \\
Interlibrary loans (Documents Delivery Service) & 1 & 0.2 \\
Information retrieval & 27 & 6.2 \\
Using audio-visual materials & 31 & 7.1 \\
Study subjects, homework & 77 & 17.7 \\
Job preparation / qualification & 14 & 3.2 \\
Utilizing electronic equipment (copiers, printers, scanners) & 25 & 5.7 \\
Meet friends & 12 & 2.8 \\
Using rest facilities & 9 & 2.1 \\
Others & 3 & 0.7 \\
Total & 436 & 100.0 \\
\hline
\end{tabular}




\subsection{The most used library space}

The following Table 7 is the results of question items that asked which space respondents use most. The number of respondents with 'no answer' was recorded. As a result, the most used library space was 'resource reading room' (53.8\%), followed by 'multimedia information square' (17.4\%), 'reading room' (12.5\%), and 'job library' $(10.3 \%)$. On the other hand, the most unused space was 'group study room' and 'serials room', both were $2.2 \%$. The main reason why the serials room is not used is most likely because most serials' articles can be accessed online due to the development of information technology.

When analyzing 'the most used library space' by gender, it was found that female users used the following library spaces often: Resource reading room, Multimedia information square, and Reading room. On the other hand, male users used the following library spaces often: Resource reading room, Reading room, and Multimedia information square.

When analyzing 'the most used library space' by year, it was found that 'Resource reading room' was the highest used library space for most years. When analyzing it by colleges, 'Resource reading room' was the highest used library space for most of the colleges. It was found that students in the College of Biomedical \& Health Science, compared to other colleges, used 'Multimedia information square' and 'Job Library' in particular.

Table 7. The most used library space

\begin{tabular}{|c|c|c|c|c|c|c|c|c|c|c|c|}
\hline & & & \multicolumn{8}{|c|}{ Library spaces } & \multirow[t]{2}{*}{ All } \\
\hline & & & $\begin{array}{l}\text { No } \\
\text { answer }\end{array}$ & $\begin{array}{l}\text { Resource } \\
\text { reading } \\
\text { room }\end{array}$ & $\begin{array}{l}\text { Serials } \\
\text { room }\end{array}$ & $\begin{array}{l}\text { Multimedia } \\
\text { information } \\
\text { square }\end{array}$ & $\begin{array}{l}\text { Job } \\
\text { Library }\end{array}$ & $\begin{array}{l}\text { Group } \\
\text { study } \\
\text { room }\end{array}$ & $\begin{array}{l}\text { Reading } \\
\text { room }\end{array}$ & Others & \\
\hline \multirow[t]{4}{*}{ Gender } & Male & freq. & 0 & 32 & 1 & 12 & 6 & 4 & 17 & 0 & 72 \\
\hline & & $\%$ & $.0 \%$ & $17.4 \%$ & $.5 \%$ & $6.5 \%$ & $3.3 \%$ & $2.2 \%$ & $9.2 \%$ & $.0 \%$ & $39.1 \%$ \\
\hline & Female & freq. & 1 & 67 & 3 & 20 & 13 & 0 & 6 & 2 & 112 \\
\hline & & $\%$ & $.5 \%$ & $36.4 \%$ & $1.6 \%$ & $10.9 \%$ & $7.1 \%$ & $.0 \%$ & $3.3 \%$ & $1.1 \%$ & $60.9 \%$ \\
\hline \multirow[t]{8}{*}{ Year } & Year 1 & freq. & 0 & 16 & 0 & 12 & 7 & 1 & 8 & 0 & 44 \\
\hline & & $\%$ & $.0 \%$ & $8.7 \%$ & $.0 \%$ & $6.5 \%$ & $3.8 \%$ & $.5 \%$ & $4.3 \%$ & $.0 \%$ & $23.9 \%$ \\
\hline & Year 2 & freq. & 0 & 16 & 2 & 3 & 5 & 1 & 5 & 0 & 32 \\
\hline & & $\%$ & $.0 \%$ & $8.7 \%$ & $1.1 \%$ & $1.6 \%$ & $2.7 \%$ & $.5 \%$ & $2.7 \%$ & $.0 \%$ & $17.4 \%$ \\
\hline & Year 3 & freq. & 1 & 24 & 1 & 9 & 2 & 2 & 6 & 1 & 46 \\
\hline & & $\%$ & $.5 \%$ & $13.0 \%$ & $.5 \%$ & $4.9 \%$ & $1.1 \%$ & $1.1 \%$ & $3.3 \%$ & $.5 \%$ & $25.0 \%$ \\
\hline & Year 4 & freq. & 0 & 43 & 1 & 8 & 5 & 0 & 4 & 1 & 62 \\
\hline & & $\%$ & $.0 \%$ & $23.4 \%$ & $.5 \%$ & $4.3 \%$ & $2.7 \%$ & $.0 \%$ & $2.2 \%$ & $.5 \%$ & $33.7 \%$ \\
\hline \multirow[t]{8}{*}{ Colleges } & Humanities & freq. & 1 & 44 & 2 & 13 & 4 & 1 & 6 & 2 & 73 \\
\hline & & $\%$ & $.5 \%$ & $23.9 \%$ & $1.1 \%$ & $7.1 \%$ & $2.2 \%$ & $.5 \%$ & $3.3 \%$ & $1.1 \%$ & $39.7 \%$ \\
\hline & Social & freq. & 0 & 23 & 0 & 6 & 2 & 1 & 5 & 0 & 37 \\
\hline & Science & $\%$ & $.0 \%$ & $12.5 \%$ & $.0 \%$ & $3.3 \%$ & $1.1 \%$ & $.5 \%$ & $2.7 \%$ & $.0 \%$ & $20.1 \%$ \\
\hline & Natural & freq. & 0 & 13 & 1 & 2 & 4 & 2 & 6 & 0 & 28 \\
\hline & Sciences & $\%$ & $.0 \%$ & $7.1 \%$ & $.5 \%$ & $1.1 \%$ & $2.2 \%$ & $1.1 \%$ & $3.3 \%$ & $.0 \%$ & $15.2 \%$ \\
\hline & Art \& & freq. & 0 & 7 & 1 & 3 & 2 & 0 & 1 & 0 & 14 \\
\hline & Design & $\%$ & $.0 \%$ & $3.8 \%$ & $.5 \%$ & $1.6 \%$ & $1.1 \%$ & $.0 \%$ & $.5 \%$ & $.0 \%$ & $7.6 \%$ \\
\hline
\end{tabular}


$Y$. H. Noh et al.
International Journal of Knowledge Content Development \& Technology Vol.1, No.1, 61-79 (June, 2011)

\begin{tabular}{|c|c|c|c|c|c|c|c|c|c|c|c|}
\hline & & & \multicolumn{8}{|c|}{ Library spaces } & \multirow[t]{2}{*}{ All } \\
\hline & & & $\begin{array}{l}\text { No } \\
\text { answer }\end{array}$ & $\begin{array}{l}\text { Resource } \\
\text { reading } \\
\text { room }\end{array}$ & $\begin{array}{l}\text { Serials } \\
\text { room }\end{array}$ & $\begin{array}{l}\text { Multimedia } \\
\text { information } \\
\text { square }\end{array}$ & $\begin{array}{l}\text { Job } \\
\text { Library }\end{array}$ & $\begin{array}{l}\text { Group } \\
\text { study } \\
\text { room }\end{array}$ & $\begin{array}{l}\text { Reading } \\
\text { room }\end{array}$ & Others & \\
\hline & \multirow{2}{*}{$\begin{array}{l}\text { Biomedical } \\
\& \text { Health } \\
\text { Science }\end{array}$} & freq. & 0 & 7 & 0 & 5 & 5 & 0 & 3 & 0 & 20 \\
\hline & & $\%$ & $.0 \%$ & $3.8 \%$ & $.0 \%$ & $2.7 \%$ & $2.7 \%$ & $.0 \%$ & $1.6 \%$ & $.0 \%$ & $10.9 \%$ \\
\hline & \multirow{4}{*}{$\begin{array}{l}\text { Global } \\
\text { Studies }\end{array}$} & freq. & 0 & 5 & 0 & 3 & 2 & 0 & 2 & 0 & 12 \\
\hline & & $\%$ & $.0 \%$ & $2.7 \%$ & $.0 \%$ & $1.6 \%$ & $1.1 \%$ & $.0 \%$ & $1.1 \%$ & $.0 \%$ & $6.5 \%$ \\
\hline \multirow[t]{2}{*}{ All } & & freq. & 1 & 99 & 4 & 32 & 19 & 4 & 23 & 2 & 184 \\
\hline & & $\%$ & $.5 \%$ & $53.8 \%$ & $2.2 \%$ & $17.4 \%$ & $10.3 \%$ & $2.2 \%$ & $12.5 \%$ & $1.1 \%$ & $100.0 \%$ \\
\hline
\end{tabular}

\subsection{The most used library materials}

Allowing the user to choose three possible responses, it was surveyed which materials they used most commonly in the library. As a result, the total number of responses was 305, excluding the 'no response'. The results are summarized in Table 8.

The rate of respondents answering that they mainly used 'general books' is the highest (53.1\%), followed by thesis (11.1\%), Electronic Information and Audio-visual material (both 10.8\%). The response rate for 'reference materials' was the lowest.

Table 8. The most used library materials

\begin{tabular}{llll}
\hline The most used library materials & Respondents & Percent \\
\hline Materials & General books & 162 & 53.1 \\
& Serials & 31 & 10.2 \\
Thesis & 34 & 11.1 \\
& Electronic Information & 33 & 10.8 \\
Audio-visual & 33 & 10.8 \\
Reference resources & 10 & 3.3 \\
Others & 2 & 0.7 \\
Total & 305 & 100.0 \\
\hline
\end{tabular}

\subsection{How to obtain their needed resources (the non-collection resources)}

The following Table 9 is the results of question items that concern the most preferred way to obtain needed materials when failing to find the wanted materials. As a result, the rate of respondents answering that they mainly contact librarians is the highest $(24.5 \%)$, followed by 'Request for Library Purchase' (19.6\%), and 'Abandon' (14.7\%). 'Asking friends and professor' was the lowest (5.4\%).

When analyzing how to obtain 'Non-collection resources' by gender, it seems that both female and male users most preferred to contact librarians. However, as a second priority, female users preferred to request for library purchase, but males preferred to search for related materials.

When analyzing how to obtain 'Non-collection resources' by year, it was analyzed that abandonment by low-years is significantly higher. As can be seen from Table 9, the higher the year, the rate 
to take active solutions increases gradually.

When analyzing the results by colleges, students in colleges of Humanities, Social Science, and Natural Sciences seem to acquire their needed resources within the library more actively. On the other hand, students in colleges of Art \& Design, Biomedical \& Health Science, and Global Studies seem reluctant to obtain needed resources within the library. The rate of abandonment was very high.

Table 9. How to obtain their needed resources (the non-collection resources)

\begin{tabular}{|c|c|c|c|c|c|c|c|c|c|c|c|}
\hline & & & \multicolumn{8}{|c|}{ How to obtain their needed resources } & \multirow[t]{2}{*}{ All } \\
\hline & & & $\begin{array}{l}\text { Contact } \\
\text { librarian }\end{array}$ & $\begin{array}{l}\text { Searching } \\
\text { related } \\
\text { materials }\end{array}$ & $\begin{array}{l}\text { Request for } \\
\text { library } \\
\text { purchase }\end{array}$ & $\begin{array}{l}\text { Using } \\
\text { other } \\
\text { libraries }\end{array}$ & $\begin{array}{l}\text { Asking to } \\
\text { friends, } \\
\text { professor }\end{array}$ & $\begin{array}{l}\text { Personal } \\
\text { purchase }\end{array}$ & Abandon & Others & \\
\hline \multirow[t]{4}{*}{ Gender } & Male & freq. & 18 & 15 & 12 & 5 & 5 & 7 & 9 & 1 & 72 \\
\hline & & $\%$ & $9.8 \%$ & $8.2 \%$ & $6.5 \%$ & $2.7 \%$ & $2.7 \%$ & $3.8 \%$ & $4.9 \%$ & $.5 \%$ & $39.1 \%$ \\
\hline & Female & freq. & 27 & 11 & 24 & 12 & 5 & 10 & 18 & 5 & 112 \\
\hline & & $\%$ & $14.7 \%$ & $6.0 \%$ & $13.0 \%$ & $6.5 \%$ & $2.7 \%$ & $5.4 \%$ & $9.8 \%$ & $2.7 \%$ & $60.9 \%$ \\
\hline \multirow[t]{8}{*}{ Year } & Year 1 & freq. & 11 & 4 & 3 & 7 & 4 & 7 & 8 & 0 & 44 \\
\hline & & $\%$ & $6.0 \%$ & $2.2 \%$ & $1.6 \%$ & $3.8 \%$ & $2.2 \%$ & $3.8 \%$ & $4.3 \%$ & $.0 \%$ & $23.9 \%$ \\
\hline & Year 2 & freq. & 8 & 4 & 6 & 1 & 2 & 2 & 8 & 1 & 32 \\
\hline & & $\%$ & $4.3 \%$ & $2.2 \%$ & $3.3 \%$ & $.5 \%$ & $1.1 \%$ & $1.1 \%$ & $4.3 \%$ & $.5 \%$ & $17.4 \%$ \\
\hline & Year 3 & freq. & 11 & 8 & 9 & 5 & 2 & 2 & 7 & 2 & 46 \\
\hline & & $\%$ & $6.0 \%$ & $4.3 \%$ & $4.9 \%$ & $2.7 \%$ & $1.1 \%$ & $1.1 \%$ & $3.8 \%$ & $1.1 \%$ & $25.0 \%$ \\
\hline & Year 4 & freq. & 15 & 10 & 18 & 4 & 2 & 6 & 4 & 3 & 62 \\
\hline & & $\%$ & $8.2 \%$ & $5.4 \%$ & $9.8 \%$ & $2.2 \%$ & $1.1 \%$ & $3.3 \%$ & $2.2 \%$ & $1.6 \%$ & $33.7 \%$ \\
\hline \multirow[t]{12}{*}{ Colleges } & Humanities & freq. & 19 & 10 & 21 & 5 & 4 & 6 & 5 & 3 & 73 \\
\hline & & $\%$ & $10.3 \%$ & $5.4 \%$ & $11.4 \%$ & $2.7 \%$ & $2.2 \%$ & $3.3 \%$ & $2.7 \%$ & $1.6 \%$ & $39.7 \%$ \\
\hline & Social & freq. & 9 & 7 & 4 & 2 & 2 & 6 & 7 & 0 & 37 \\
\hline & Science & $\%$ & $4.9 \%$ & $3.8 \%$ & $2.2 \%$ & $1.1 \%$ & $1.1 \%$ & $3.3 \%$ & $3.8 \%$ & $.0 \%$ & $20.1 \%$ \\
\hline & Natural & freq. & 8 & 5 & 5 & 3 & 2 & 1 & 3 & 1 & 28 \\
\hline & Sciences & $\%$ & $4.3 \%$ & $2.7 \%$ & $2.7 \%$ & $1.6 \%$ & $1.1 \%$ & $.5 \%$ & $1.6 \%$ & $.5 \%$ & $15.2 \%$ \\
\hline & Art \& & freq. & 0 & 2 & 2 & 1 & 0 & 4 & 4 & 1 & 14 \\
\hline & Design & $\%$ & $.0 \%$ & $1.1 \%$ & $1.1 \%$ & $.5 \%$ & $.0 \%$ & $2.2 \%$ & $2.2 \%$ & $.5 \%$ & $7.6 \%$ \\
\hline & Biomedical & freq. & 5 & 2 & 3 & 4 & 1 & 0 & 5 & 0 & 20 \\
\hline & $\begin{array}{l}\text { \& Health } \\
\text { Science }\end{array}$ & $\%$ & $2.7 \%$ & $1.1 \%$ & $1.6 \%$ & $2.2 \%$ & $.5 \%$ & $.0 \%$ & $2.7 \%$ & $.0 \%$ & $10.9 \%$ \\
\hline & Global & freq. & 4 & 0 & 1 & 2 & 1 & 0 & 3 & 1 & 12 \\
\hline & Studies & $\%$ & $2.2 \%$ & $.0 \%$ & $.5 \%$ & $1.1 \%$ & $.5 \%$ & $.0 \%$ & $1.6 \%$ & $.5 \%$ & $6.5 \%$ \\
\hline \multirow[t]{2}{*}{ All } & & freq. & 45 & 26 & 36 & 17 & 10 & 17 & 27 & 6 & 184 \\
\hline & & $\%$ & $24.5 \%$ & $14.1 \%$ & $19.6 \%$ & $9.2 \%$ & $5.4 \%$ & $9.2 \%$ & $14.7 \%$ & $3.3 \%$ & $100.0 \%$ \\
\hline
\end{tabular}

\subsection{How to know how to use the library facilities}

The following Table 10 is the results of question items regarding the most preferred way to know how to use library facilities. As a result, the rate of respondents answering that they mainly contact librarians is the highest (46.2\%), followed by 'refer to library guide' $(20.1 \%)$, and 'no difficulty' $(15.8 \%)$. The rate of 'asking nearby users' was the lowest at $7.6 \%$. The rate at which' abandoned 
the use of facilities' was chosen is not low at almost $10 \%$.

When analyzing results by gender, year, and colleges, 'How to know how to use the facility' was showing a similar phenomenon with the above 'how to get the resources'.

Table 10. How to know how to use the library facilities

\begin{tabular}{|c|c|c|c|c|c|c|c|c|c|}
\hline & & & \multicolumn{6}{|c|}{ How to know how to use the library facilities } & \multirow[t]{2}{*}{ All } \\
\hline & & & $\begin{array}{l}\text { Contact } \\
\text { librarian }\end{array}$ & $\begin{array}{l}\text { Asking to } \\
\text { users around }\end{array}$ & $\begin{array}{l}\text { Refer to } \\
\text { library guides }\end{array}$ & No difficulty & Abandon & Others & \\
\hline \multirow[t]{4}{*}{ Gender } & Male & freq. & 27 & 8 & 18 & 10 & 9 & 0 & 72 \\
\hline & & $\%$ & $14.7 \%$ & $4.3 \%$ & $9.8 \%$ & $5.4 \%$ & $4.9 \%$ & $.0 \%$ & $39.1 \%$ \\
\hline & Female & freq. & 58 & 6 & 19 & 19 & 7 & 3 & 112 \\
\hline & & $\%$ & $31.5 \%$ & $3.3 \%$ & $10.3 \%$ & $10.3 \%$ & $3.8 \%$ & $1.6 \%$ & $60.9 \%$ \\
\hline \multirow[t]{8}{*}{ Year } & Year 1 & freq. & 20 & 8 & 9 & 3 & 4 & 0 & 44 \\
\hline & & $\%$ & $10.9 \%$ & $4.3 \%$ & $4.9 \%$ & $1.6 \%$ & $2.2 \%$ & $.0 \%$ & $23.9 \%$ \\
\hline & Year 2 & freq. & 12 & 3 & 5 & 6 & 6 & 0 & 32 \\
\hline & & $\%$ & $6.5 \%$ & $1.6 \%$ & $2.7 \%$ & $3.3 \%$ & $3.3 \%$ & $.0 \%$ & $17.4 \%$ \\
\hline & Year 3 & freq. & 21 & 2 & 13 & 8 & 2 & 0 & 46 \\
\hline & & $\%$ & $11.4 \%$ & $1.1 \%$ & $7.1 \%$ & $4.3 \%$ & $1.1 \%$ & $.0 \%$ & $25.0 \%$ \\
\hline & Year 4 & freq. & 32 & 1 & 10 & 12 & 4 & 3 & 62 \\
\hline & & $\%$ & $17.4 \%$ & $.5 \%$ & $5.4 \%$ & $6.5 \%$ & $2.2 \%$ & $1.6 \%$ & $33.7 \%$ \\
\hline \multirow[t]{12}{*}{ Colleges } & Humanities & freq. & 35 & 4 & 11 & 17 & 4 & 2 & 73 \\
\hline & & $\%$ & $19.0 \%$ & $2.2 \%$ & $6.0 \%$ & $9.2 \%$ & $2.2 \%$ & $1.1 \%$ & $39.7 \%$ \\
\hline & Social Science & freq. & 16 & 2 & 8 & 5 & 6 & 0 & 37 \\
\hline & & $\%$ & $8.7 \%$ & $1.1 \%$ & $4.3 \%$ & $2.7 \%$ & $3.3 \%$ & $.0 \%$ & $20.1 \%$ \\
\hline & Natural & freq. & 13 & 3 & 9 & 3 & 0 & 0 & 28 \\
\hline & Sciences & $\%$ & $7.1 \%$ & $1.6 \%$ & $4.9 \%$ & $1.6 \%$ & $.0 \%$ & $.0 \%$ & $15.2 \%$ \\
\hline & Art \& Design & freq. & 6 & 2 & 4 & 1 & 1 & 0 & 14 \\
\hline & & $\%$ & $3.3 \%$ & $1.1 \%$ & $2.2 \%$ & $.5 \%$ & $.5 \%$ & $.0 \%$ & $7.6 \%$ \\
\hline & Biomedical \& & freq. & 9 & 2 & 3 & 3 & 3 & 0 & 20 \\
\hline & Health Science & $\%$ & $4.9 \%$ & $1.1 \%$ & $1.6 \%$ & $1.6 \%$ & $1.6 \%$ & $.0 \%$ & $10.9 \%$ \\
\hline & Global Studies & freq. & 6 & 1 & 2 & 0 & 2 & 1 & 12 \\
\hline & & $\%$ & $3.3 \%$ & $.5 \%$ & $1.1 \%$ & $.0 \%$ & $1.1 \%$ & $.5 \%$ & $6.5 \%$ \\
\hline \multirow[t]{2}{*}{ All } & & freq. & 85 & 14 & 37 & 29 & 16 & 3 & 184 \\
\hline & & $\%$ & $46.2 \%$ & $7.6 \%$ & $20.1 \%$ & $15.8 \%$ & $8.7 \%$ & $1.6 \%$ & $100.0 \%$ \\
\hline
\end{tabular}

\subsection{Satisfaction with lending period}

The following Table 11 is about 'user satisfaction with the lending period'. According to the current library regulations, the loan period for undergraduate students is 7 days.

As a result, it was shown that the loan period that users preferred most was 10 days (43.5\%), followed by 15 days $(35.3 \%)$, and 20 days (10.9\%). A similar phenomenon appeared in results comparing by gender, year, and colleges. However, it was shown that students of Colleges of Natural Sciences, Biomedical \& Health Science favored a long load period of 20 days the most highly. 
72 International Journal of Knowledge Content Development \& al. Technology Vol.1, No.1, $61-79$ (June, 2011)

Table 11. Satisfaction with lending period

\begin{tabular}{|c|c|c|c|c|c|c|c|c|}
\hline & & & \multicolumn{5}{|c|}{ Loan periods } & \multirow[t]{2}{*}{ All } \\
\hline & & & 5 days & 7 days & 10 days & 15 days & 20 days & \\
\hline \multirow[t]{4}{*}{ Gender } & Male & freq. & 2 & 9 & 34 & 21 & 6 & 72 \\
\hline & & $\%$ & $1.1 \%$ & $4.9 \%$ & $18.5 \%$ & $11.4 \%$ & $3.3 \%$ & $39.1 \%$ \\
\hline & Female & freq. & 2 & 6 & 46 & 44 & 14 & 112 \\
\hline & & $\%$ & $1.1 \%$ & $3.3 \%$ & $25.0 \%$ & $23.9 \%$ & $7.6 \%$ & $60.9 \%$ \\
\hline \multirow[t]{8}{*}{ Year } & Year 1 & freq. & 2 & 7 & 16 & 9 & 10 & 44 \\
\hline & & $\%$ & $1.1 \%$ & $3.8 \%$ & $8.7 \%$ & $4.9 \%$ & $5.4 \%$ & $23.9 \%$ \\
\hline & Year 2 & freq. & 1 & 2 & 17 & 11 & 1 & 32 \\
\hline & & $\%$ & $.5 \%$ & $1.1 \%$ & $9.2 \%$ & $6.0 \%$ & $.5 \%$ & $17.4 \%$ \\
\hline & Year 3 & freq. & 0 & 2 & 18 & 21 & 5 & 46 \\
\hline & & $\%$ & $.0 \%$ & $1.1 \%$ & $9.8 \%$ & $11.4 \%$ & $2.7 \%$ & $25.0 \%$ \\
\hline & Year 4 & freq. & 1 & 4 & 29 & 24 & 4 & 62 \\
\hline & & $\%$ & $.5 \%$ & $2.2 \%$ & $15.8 \%$ & $13.0 \%$ & $2.2 \%$ & $33.7 \%$ \\
\hline \multirow[t]{12}{*}{ Colleges } & Humanities & freq. & 1 & 3 & 36 & 28 & 5 & 73 \\
\hline & & $\%$ & $.5 \%$ & $1.6 \%$ & $19.6 \%$ & $15.2 \%$ & $2.7 \%$ & $39.7 \%$ \\
\hline & Social Science & freq. & 2 & 3 & 16 & 14 & 2 & 37 \\
\hline & & $\%$ & $1.1 \%$ & $1.6 \%$ & $8.7 \%$ & $7.6 \%$ & $1.1 \%$ & $20.1 \%$ \\
\hline & Natural Sciences & freq. & 0 & 5 & 7 & 10 & 6 & 28 \\
\hline & & $\%$ & $.0 \%$ & $2.7 \%$ & $3.8 \%$ & $5.4 \%$ & $3.3 \%$ & $15.2 \%$ \\
\hline & Art \& Design & freq. & 1 & 1 & 7 & 3 & 2 & 14 \\
\hline & & $\%$ & $.5 \%$ & $.5 \%$ & $3.8 \%$ & $1.6 \%$ & $1.1 \%$ & $7.6 \%$ \\
\hline & Biomedical \& & freq. & 0 & 2 & 6 & 8 & 4 & 20 \\
\hline & Health Science & $\%$ & $.0 \%$ & $1.1 \%$ & $3.3 \%$ & $4.3 \%$ & $2.2 \%$ & $10.9 \%$ \\
\hline & Global Studies & freq. & 0 & 1 & 8 & 2 & 1 & 12 \\
\hline & & $\%$ & $.0 \%$ & $.5 \%$ & $4.3 \%$ & $1.1 \%$ & $.5 \%$ & $6.5 \%$ \\
\hline \multirow[t]{2}{*}{ All } & & freq. & 4 & 15 & 80 & 65 & 20 & 184 \\
\hline & & $\%$ & $2.2 \%$ & $8.2 \%$ & $43.5 \%$ & $35.3 \%$ & $10.9 \%$ & $100.0 \%$ \\
\hline
\end{tabular}

\subsection{Satisfaction with number of borrowed books}

The following Table 12 is about 'user satisfaction with number of borrowed books'. According to the current library regulations, the number of borrowed books allowed for undergraduate students is 7 volumes.

Results showed that users were satisfied with the current limit of volumes for borrowing. A similar phenomenon appeared in results comparing by gender, year, and colleges. However, it was shown that students of Colleges of Biomedical \& Health Science favored less volumes (5 volumes) for borrowing the most highly. 
Y. H. Noh et al.
International Journal of Knowledge Content Development \& Technology Vol.1, No.1, 61-79 (June, 2011)

Table 12. Satisfaction with number of borrowed books

\begin{tabular}{|c|c|c|c|c|c|c|c|c|}
\hline & & & \multicolumn{5}{|c|}{ The number of borrowed books } & \multirow[t]{2}{*}{ All } \\
\hline & & & No answers & 5 volumes & 7 volumes & 10 volumes & 15 volumes & \\
\hline \multirow[t]{4}{*}{ Gender } & Male & freq. & 1 & 17 & 37 & 17 & 0 & 72 \\
\hline & & $\%$ & $.5 \%$ & $9.2 \%$ & $20.1 \%$ & $9.2 \%$ & $.0 \%$ & $39.1 \%$ \\
\hline & Female & freq. & 0 & 34 & 43 & 26 & 9 & 112 \\
\hline & & $\%$ & $.0 \%$ & $18.5 \%$ & $23.4 \%$ & $14.1 \%$ & $4.9 \%$ & $60.9 \%$ \\
\hline \multirow[t]{8}{*}{ Year } & Year 1 & freq. & 0 & 23 & 14 & 6 & 1 & 44 \\
\hline & & $\%$ & $.0 \%$ & $12.5 \%$ & $7.6 \%$ & $3.3 \%$ & $.5 \%$ & $23.9 \%$ \\
\hline & Year 2 & freq. & 1 & 8 & 13 & 7 & 3 & 32 \\
\hline & & $\%$ & $.5 \%$ & $4.3 \%$ & $7.1 \%$ & $3.8 \%$ & $1.6 \%$ & $17.4 \%$ \\
\hline & Year 3 & freq. & 0 & 6 & 29 & 9 & 2 & 46 \\
\hline & & $\%$ & $.0 \%$ & $3.3 \%$ & $15.8 \%$ & $4.9 \%$ & $1.1 \%$ & $25.0 \%$ \\
\hline & Year 4 & freq. & 0 & 14 & 24 & 21 & 3 & 62 \\
\hline & & $\%$ & $.0 \%$ & $7.6 \%$ & $13.0 \%$ & $11.4 \%$ & $1.6 \%$ & $33.7 \%$ \\
\hline \multirow[t]{12}{*}{ Colleges } & Humanities & freq. & 1 & 13 & 28 & 26 & 5 & 73 \\
\hline & & $\%$ & $.5 \%$ & $7.1 \%$ & $15.2 \%$ & $14.1 \%$ & $2.7 \%$ & $39.7 \%$ \\
\hline & Social Science & freq. & 0 & 13 & 17 & 7 & 0 & 37 \\
\hline & & $\%$ & $.0 \%$ & $7.1 \%$ & $9.2 \%$ & $3.8 \%$ & $.0 \%$ & $20.1 \%$ \\
\hline & Natural Sciences & freq. & 0 & 6 & 18 & 2 & 2 & 28 \\
\hline & & $\%$ & $.0 \%$ & $3.3 \%$ & $9.8 \%$ & $1.1 \%$ & $1.1 \%$ & $15.2 \%$ \\
\hline & Art \& Design & freq. & 0 & 5 & 6 & 1 & 2 & 14 \\
\hline & & $\%$ & $.0 \%$ & $2.7 \%$ & $3.3 \%$ & $.5 \%$ & $1.1 \%$ & $7.6 \%$ \\
\hline & Biomedical \& & freq. & 0 & 9 & 8 & 3 & 0 & 20 \\
\hline & Health Science & $\%$ & $.0 \%$ & $4.9 \%$ & $4.3 \%$ & $1.6 \%$ & $.0 \%$ & $10.9 \%$ \\
\hline & Global Studies & freq. & 0 & 5 & 3 & 4 & 0 & 12 \\
\hline & & $\%$ & $.0 \%$ & $2.7 \%$ & $1.6 \%$ & $2.2 \%$ & $.0 \%$ & $6.5 \%$ \\
\hline \multirow[t]{2}{*}{ All } & & freq. & 1 & 51 & 80 & 43 & 9 & 184 \\
\hline & & $\%$ & $.5 \%$ & $27.7 \%$ & $43.5 \%$ & $23.4 \%$ & $4.9 \%$ & $100.0 \%$ \\
\hline
\end{tabular}

\subsection{Satisfaction with library services}

The items for investigating satisfaction of library services are four as follows: 'Librarians', 'User services', 'Document delivery and interlibrary loan', 'homepage configuration and use', and 'opening hours'. User satisfaction of library services was surveyed by a Likert five-point scale. As a result, It was shown that they were satisfied with librarians' user services at $52.2 \%$, 'document delivery and interlibrary loan' at $41.3 \%$, and 'opening hours' at $38 \%$. However, dissatisfaction about 'opening hours' was significantly higher at $28.8 \%$. 
74 International Journal of Knowledge Content Development \& Technology Vol.1, No.1, $61-79$ (June, 2011)

Table 13. Satisfaction with library services

\begin{tabular}{|c|c|c|c|c|c|c|c|c|}
\hline & \multicolumn{8}{|c|}{ Satisfaction with library service } \\
\hline & & $\begin{array}{l}\text { No } \\
\text { answer }\end{array}$ & $\begin{array}{l}\text { Very } \\
\text { Satisfied }\end{array}$ & Satisfaction & $\begin{array}{l}\text { Common } \\
\text { /neutral }\end{array}$ & Dissatisfaction & $\begin{array}{l}\text { Very } \\
\text { dissatisfied }\end{array}$ & Total \\
\hline \multirow{2}{*}{$\begin{array}{l}\text { Librarians' library } \\
\text { service }\end{array}$} & freq. & 3 & 23 & 73 & 75 & 9 & 1 & 184 \\
\hline & $\%$ & 1.6 & 12.5 & 39.7 & 40.8 & 4.9 & .5 & 100.0 \\
\hline \multirow{2}{*}{$\begin{array}{l}\text { Document delivery } \\
\text { and interlibrary loan }\end{array}$} & freq. & 4 & 11 & 65 & 85 & 16 & 3 & 184 \\
\hline & $\%$ & 2.2 & 6.0 & 35.3 & 46.2 & 8.7 & 1.6 & 100.0 \\
\hline \multirow{2}{*}{$\begin{array}{l}\text { Homepage } \\
\text { configuration } \\
\text { and use }\end{array}$} & freq. & 4 & 20 & 67 & 80 & 12 & 1 & 184 \\
\hline & $\%$ & 2.2 & 10.9 & 36.4 & 43.5 & 6.5 & .5 & 100.0 \\
\hline \multirow{2}{*}{$\begin{array}{l}\text { Opening } \\
\text { hours }\end{array}$} & freq. & 4 & 14 & 56 & 57 & 43 & 10 & 184 \\
\hline & $\%$ & 2.2 & 7.6 & 30.4 & 31.0 & 23.4 & 5.4 & 100.0 \\
\hline
\end{tabular}

\subsection{Recency of the collection}

The items for investigating satisfaction of collection's recency are six as follows in Table 14. User satisfaction with it was surveyed by a Likert five-point scale. 'Recency of general books' showed the highest satisfaction at $64.6 \%$. On the other hand, 'Recency of audio-visual materials' showed the lowest satisfaction compared to the others.

Table 14. Recency of collection

\begin{tabular}{|c|c|c|c|c|c|c|c|c|}
\hline & \multicolumn{8}{|c|}{ collection's recency } \\
\hline & & $\begin{array}{l}\text { No } \\
\text { answer }\end{array}$ & $\begin{array}{l}\text { Very } \\
\text { Satisfied }\end{array}$ & Satisfaction & $\begin{array}{l}\text { Common } \\
\text { /neutral }\end{array}$ & Dissatisfaction & $\begin{array}{l}\text { Very } \\
\text { dissatisfied }\end{array}$ & Total \\
\hline \multirow{2}{*}{$\begin{array}{l}\text { Recency of } \\
\text { general books }\end{array}$} & freq. & 3 & 33 & 86 & 42 & 18 & 2 & 184 \\
\hline & $\%$ & 1.6 & 17.9 & 46.7 & 22.8 & 9.8 & 1.1 & 100.0 \\
\hline \multirow{2}{*}{$\begin{array}{l}\text { Recency of } \\
\text { thesis }\end{array}$} & freq. & 4 & 13 & 51 & 93 & 20 & 2 & 184 \\
\hline & $\%$ & 2.2 & 7.1 & 27.7 & 50.5 & 10.9 & 1.1 & 100.0 \\
\hline \multirow{2}{*}{$\begin{array}{l}\text { Recency of } \\
\text { serials }\end{array}$} & freq. & 4 & 17 & 69 & 82 & 11 & 1 & 184 \\
\hline & $\%$ & 2.2 & 9.2 & 37.5 & 44.6 & 6.0 & .5 & 100.0 \\
\hline \multirow{2}{*}{$\begin{array}{l}\text { Recency of } \\
\text { electronic } \\
\text { materials }\end{array}$} & freq. & 4 & 22 & 62 & 81 & 15 & 0 & 184 \\
\hline & $\%$ & 2.2 & 12.0 & 33.7 & 44.0 & 8.2 & .0 & 100.0 \\
\hline \multirow{2}{*}{$\begin{array}{l}\text { Recency of } \\
\text { audio-visual } \\
\text { materials }\end{array}$} & freq. & 4 & 22 & 61 & 68 & 28 & 1 & 184 \\
\hline & $\%$ & 2.2 & 12.0 & 33.2 & 37.0 & 15.2 & .5 & 100.0 \\
\hline \multirow{2}{*}{$\begin{array}{l}\text { Recency of } \\
\text { reference books }\end{array}$} & freq. & 5 & 18 & 50 & 100 & 10 & 1 & 184 \\
\hline & $\%$ & 2.7 & 9.8 & 27.2 & 54.3 & 5.4 & .5 & 100.0 \\
\hline
\end{tabular}

\subsection{Diversity of holdings}

The items for investigating satisfaction with the collection's diversity are six as follows in Table 15. User satisfaction with it was surveyed by a Likert five-point scale. 'Diversity of general books' showed the highest satisfaction at 59.3\%. On the other hand, 'Diversity of audio-visual materials' showed the lowest satisfaction compared to the others. It was found that the satisfaction with the collection's diversity was relatively low. 
Table 15. Diversity of collection

\begin{tabular}{|c|c|c|c|c|c|c|c|c|}
\hline & \multicolumn{8}{|c|}{ Diversity of collection } \\
\hline & & $\begin{array}{l}\text { No } \\
\text { answer }\end{array}$ & $\begin{array}{l}\text { Very } \\
\text { Satisfied }\end{array}$ & Satisfaction & $\begin{array}{l}\text { Common } \\
\text { /neutral }\end{array}$ & Dissatisfaction & $\begin{array}{l}\text { Very } \\
\text { dissatisfied }\end{array}$ & Total \\
\hline \multirow{2}{*}{$\begin{array}{l}\text { Diversity of } \\
\text { general books }\end{array}$} & freq. & 3 & 27 & 82 & 56 & 14 & 2 & 184 \\
\hline & $\%$ & 1.6 & 14.7 & 44.6 & 30.4 & 7.6 & 1.1 & 100.0 \\
\hline \multirow{2}{*}{$\begin{array}{l}\text { Diversity of } \\
\text { serials }\end{array}$} & freq. & 4 & 15 & 70 & 80 & 13 & 2 & 184 \\
\hline & $\%$ & 2.2 & 8.2 & 38.0 & 43.5 & 7.1 & 1.1 & 100.0 \\
\hline \multirow{2}{*}{$\begin{array}{l}\text { Diversity of } \\
\text { thesis }\end{array}$} & freq. & 4 & 10 & 53 & 97 & 19 & 1 & 184 \\
\hline & $\%$ & 2.2 & 5.4 & 28.8 & 52.7 & 10.3 & .5 & 100.0 \\
\hline \multirow{2}{*}{$\begin{array}{l}\text { Diversity of } \\
\text { electronic } \\
\text { materials }\end{array}$} & freq. & 4 & 19 & 57 & 88 & 13 & 3 & 184 \\
\hline & $\%$ & 2.2 & 10.3 & 31.0 & 47.8 & 7.1 & 1.6 & 100.0 \\
\hline \multirow{2}{*}{$\begin{array}{l}\text { Diversity of } \\
\text { audio-visual } \\
\text { materials }\end{array}$} & freq. & 4 & 14 & 63 & 82 & 20 & 1 & 184 \\
\hline & $\%$ & 2.2 & 7.6 & 34.2 & 44.6 & 10.9 & .5 & 100.0 \\
\hline \multirow{2}{*}{$\begin{array}{l}\text { Diversity of } \\
\text { reference } \\
\text { resources }\end{array}$} & freq. & 4 & 11 & 53 & 103 & 11 & 2 & 184 \\
\hline & $\%$ & 2.2 & 6.0 & 28.8 & 56.0 & 6.0 & 1.1 & 100.0 \\
\hline
\end{tabular}

\subsection{Satisfaction with facilities and environment}

The items for investigating satisfaction with 'Facilities and Environment' are shown in the following Table 16. User satisfaction with them was surveyed by a Likert five-point scale. User satisfaction with facilities and environment was very low, excepting the 'Loan Desk'. Especially, satisfaction with the Reading Room, Study Room, Soundproofing, and Air conditioning was very low. Therefore, the library needs to make an effort to improve the library's circumstance and facilities.

Table 16. Satisfaction for facilities and environment

\begin{tabular}{|c|c|c|c|c|c|c|c|c|}
\hline & & $\begin{array}{l}\text { No } \\
\text { answer }\end{array}$ & $\begin{array}{l}\text { Very } \\
\text { Satisfied }\end{array}$ & Satisfaction & $\begin{array}{l}\text { Common } \\
\text { /neutral }\end{array}$ & Dissatisfaction & $\begin{array}{l}\text { Very } \\
\text { dissatisfied }\end{array}$ & Total \\
\hline \multirow[t]{2}{*}{ Loan Desk } & freq. & 3 & 26 & 98 & 48 & 8 & 1 & 184 \\
\hline & $\%$ & 1.6 & 14.1 & 53.3 & 26.1 & 4.3 & .5 & 100.0 \\
\hline \multirow[t]{2}{*}{ Reading Room } & freq. & 0 & 0 & 70 & 58 & 29 & 5 & 184 \\
\hline & $\%$ & 0 & 0 & 38.0 & 31.5 & 15.8 & 2.7 & 100.0 \\
\hline \multirow{2}{*}{$\begin{array}{l}\text { Bookshelves \& } \\
\text { Reading Tables }\end{array}$} & freq. & 4 & 13 & 74 & 73 & 19 & 1 & 184 \\
\hline & $\%$ & 2.2 & 7.1 & 40.2 & 39.7 & 10.3 & .5 & 100.0 \\
\hline \multirow[t]{2}{*}{ Study room } & freq. & 6 & 16 & 55 & 77 & 28 & 2 & 184 \\
\hline & $\%$ & 3.3 & 8.7 & 29.9 & 41.8 & 15.2 & 1.1 & 100.0 \\
\hline \multirow[t]{2}{*}{ Job Library } & freq. & 4 & 35 & 77 & 55 & 12 & 1 & 184 \\
\hline & $\%$ & 2.2 & 19.0 & 41.8 & 29.9 & 6.5 & .5 & 100.0 \\
\hline \multirow{2}{*}{$\begin{array}{l}\text { Multimedia } \\
\text { Information Square }\end{array}$} & freq. & 4 & 33 & 96 & 40 & 10 & 1 & 184 \\
\hline & $\%$ & 2.2 & 17.9 & 52.2 & 21.7 & 5.4 & .5 & 100.0 \\
\hline \multirow{2}{*}{$\begin{array}{l}\text { Audio-visual } \\
\text { facilities }\end{array}$} & freq. & 5 & 27 & 71 & 63 & 16 & 2 & 184 \\
\hline & $\%$ & 2.7 & 14.7 & 38.6 & 34.2 & 8.7 & 1.1 & 100.0 \\
\hline \multirow[t]{2}{*}{ Air-conditioning } & freq. & 5 & 26 & 82 & 39 & 29 & 3 & 184 \\
\hline & $\%$ & 2.7 & 14.1 & 44.6 & 21.2 & 15.8 & 1.6 & 100.0 \\
\hline \multirow[t]{2}{*}{ Soundproofing } & freq. & 5 & 8 & 42 & 69 & 49 & 11 & 184 \\
\hline & $\%$ & 2.7 & 4.3 & 22.8 & 37.5 & 26.6 & 6.0 & 100.0 \\
\hline
\end{tabular}


76 International Journal of Knowledge Content Development \& Technology Vol.1, No.1, $61-79$ (June, 2011)

\begin{tabular}{|c|c|c|c|c|c|c|c|c|}
\hline & & $\begin{array}{l}\text { No } \\
\text { answer }\end{array}$ & $\begin{array}{l}\text { Very } \\
\text { Satisfied }\end{array}$ & Satisfaction & $\begin{array}{l}\text { Common } \\
\text { /neutral }\end{array}$ & Dissatisfaction & $\begin{array}{l}\text { Very } \\
\text { dissatisfied }\end{array}$ & Total \\
\hline \multirow[t]{2}{*}{ Rest areas } & freq. & 4 & 19 & 84 & 57 & 15 & 5 & 184 \\
\hline & $\%$ & 2.2 & 10.3 & 45.7 & 31.0 & 8.2 & 2.7 & 100.0 \\
\hline \multirow[t]{2}{*}{ Cleanliness } & freq. & 4 & 26 & 83 & 55 & 13 & 3 & 184 \\
\hline & $\%$ & 2.2 & 14.1 & 45.1 & 29.9 & 7.1 & 1.6 & 100.0 \\
\hline
\end{tabular}

\subsection{The need for additional space}

The items for investigating the need for additional space are as follows in Table 17. As a result, 'Book Cafe \& Relaxation space' showed the highest demand at 38.6\%, followed by 'Study room $\&$ discussion area' (18.5\%), and 'Cultural Program Space' (16.3\%).

Table 17. The need for additional space

\begin{tabular}{lllllllll}
\hline & \multicolumn{2}{l}{ The need for additional } & space & & & & \\
\cline { 2 - 8 } & $\begin{array}{l}\text { No } \\
\text { answer }\end{array}$ & $\begin{array}{l}\text { Book Cafe } \\
\text { \& Relaxation } \\
\text { space }\end{array}$ & $\begin{array}{l}\text { Media studio } \\
\text { space }\end{array}$ & $\begin{array}{l}\text { Personal } \\
\text { notebook } \\
\text { space }\end{array}$ & $\begin{array}{l}\text { Cultural } \\
\text { Program } \\
\text { Space }\end{array}$ & $\begin{array}{l}\text { Study room } \\
\text { \& discussion } \\
\text { area }\end{array}$ & Others & Total \\
\hline freq & 2 & 71 & 20 & 23 & 30 & 34 & 4 & 184 \\
$\%$ & 1.1 & 38.6 & 10.9 & 12.5 & 16.3 & 18.5 & 2.2 & 100.0 \\
\hline
\end{tabular}

\subsection{User training}

In the section surveying user training, questions about number of user education, user education awareness, and awareness of the need for user education were investigated. As shown in Table 18 , the rate of users who don't know if there is user education was very high at $70.7 \%$. The rate of users who have no experience with user education was $83.7 \%$.

We analyzed by cross-analysis to investigate whether or not there are any relationships between these two variables. As shown in Table 18, users who don't know about the library's user education program have never been trained at the library. However, the approximately $40 \%$ of users who know about it did not receive user education. This means that the library does not make enough effort to promote their user education services.

Table 18. User education awareness and Number of user education taken

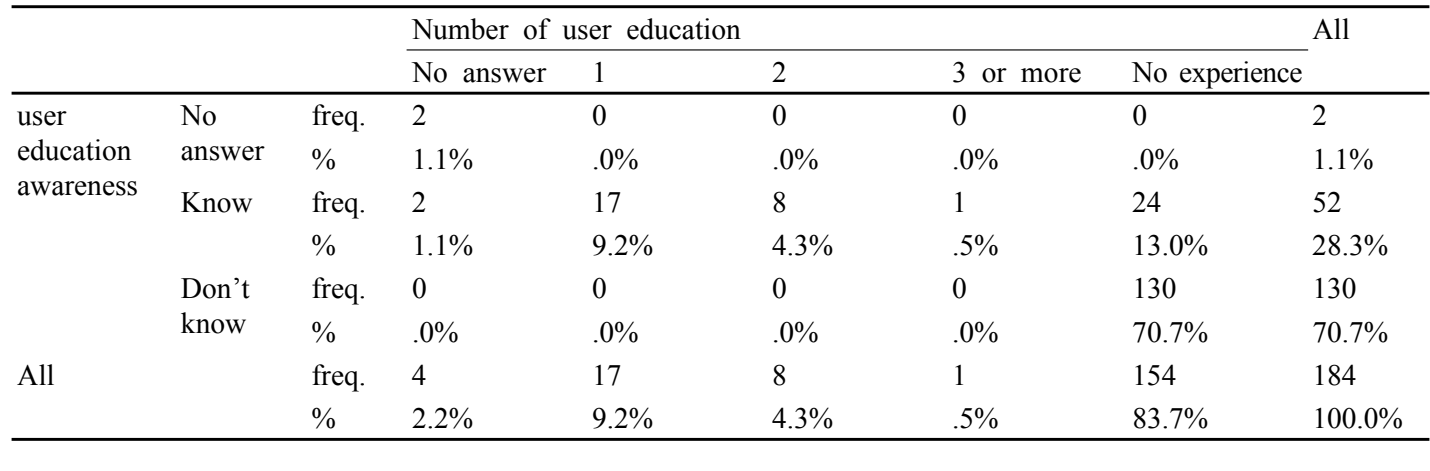


The following Table 19 is the results of surveying the users' awareness of user education's necessity. $63.1 \%$ respondents answered that user education programs are necessary, $17.4 \%$ of them said that they are strongly needed. Users responding that user education programs are not necessary were only $4.4 \%$. Therefore, libraries are required to provide user education programs more actively. In addition, users who know about the user education program responded that user education programs are required. $41 \%$ of users not knowing about the user education program responded that user education programs are required.

Table 19. Awareness of the need for user education

\begin{tabular}{|c|c|c|c|c|c|c|c|c|c|}
\hline & & & \multicolumn{6}{|c|}{ awareness of the need for user education } & \multirow[t]{2}{*}{ All } \\
\hline & & & $\begin{array}{l}\text { No } \\
\text { answer }\end{array}$ & $\begin{array}{l}\text { Very } \\
\text { necessary }\end{array}$ & necessary & Commons & Unnecessarily & $\begin{array}{l}\text { Very } \\
\text { unnecessary }\end{array}$ & \\
\hline \multirow{6}{*}{$\begin{array}{l}\text { user } \\
\text { education } \\
\text { awareness }\end{array}$} & No & freq. & 2 & 0 & 0 & 0 & 0 & 0 & 2 \\
\hline & answer & $\%$ & $1.1 \%$ & $.0 \%$ & $.0 \%$ & $.0 \%$ & $.0 \%$ & $.0 \%$ & $1.1 \%$ \\
\hline & Know & freq. & 7 & 12 & 27 & 6 & 0 & 0 & 52 \\
\hline & & $\%$ & $3.8 \%$ & $6.5 \%$ & $14.7 \%$ & $3.3 \%$ & $.0 \%$ & $.0 \%$ & $28.3 \%$ \\
\hline & Don't & freq. & 4 & 20 & 57 & 41 & 6 & 2 & 130 \\
\hline & know & $\%$ & $2.2 \%$ & $10.9 \%$ & $31.0 \%$ & $22.3 \%$ & $3.3 \%$ & $1.1 \%$ & $70.7 \%$ \\
\hline \multirow[t]{2}{*}{ All } & & freq. & 13 & 32 & 84 & 47 & 6 & 2 & 184 \\
\hline & & All \% & $7.1 \%$ & $17.4 \%$ & $45.7 \%$ & $25.5 \%$ & $3.3 \%$ & $1.1 \%$ & $100.0 \%$ \\
\hline
\end{tabular}

\subsection{Other requirements}

In addition, requirements that users commented upon at the questionnaire question 'Other suggestions' are summarized as follows:

(1) lack of recent data

(2) Homepage renewal

(3) Replacing and expanding facilities (tables, chairs, computers, cooling and heating)

(4) Extending the library opening hours

(5) Lack of user education

(6) Lack of staff's kindness

(7) Lack of reading room

(8) Establishing the lounge for relaxation

(9) Supplement of major publications

(10) Improve cleanliness

(11) Lack of study rooms

(12) Not well soundproofed

(13) Improving the service process and speed

(14) Old compared to the other campuses

(15) New library building 


\section{Discussion \& Conclusions}

Academic libraries are places for providing information needed by universities' members. Academic libraries have a role in effectively providing information resources which their academic members need for teaching and research activities. These days, academic libraries play these fundamental roles, as well as transforming into a complex space for communication, relaxation, and information commons.

According to the advancing of information technology, Korean academic libraries have been continually striving to reflect environmental changes to their libraries and meet users' needs in terms of building, remodeling, information resources, facilities, and services. This study purposed to discover whether or not academic libraries are actually reflecting these changing roles, selected $\mathrm{K}$ University as the research target and surveyed user satisfaction there.

Findings are summarized as the following seven items. First, the frequency of library visits at University $\mathrm{K}$ was on the high side. When analyzing it by gender, year, and colleges, female students, higher years, and College of Humanities recorded higher compare to others.

Second, the primary purpose of using the academic library was associated with learning or reading, therefore it can be said that users' library using purposes are related to learning and reading. On the other hand, the rate of respondents who visit for leisure was very low (about 5\%). This phenomenon could be occurring because academic library users recognize the library as a place for learning, but it could be because their library is not equipped with enough facilities for leisure, or is not served as information commons space.

Third, the most used library space was 'resource reading room', followed by 'multimedia information square', and 'reading room'. The main reason why the serials room is not used is most likely because most serials' articles can be accessed online due to the development of information technology.

Fourth, the most used library materials were 'general books', the most unused were 'reference books'. The reasons why users do not use the reference materials seem to be due to internet's resources. In the past, users came to the library to use reference resources such as maps, dictionaries, encyclopedias, guides, bibliographic reference sources, and so on. However, such data are available on the internet. For example Google Maps, Wikipedia Encyclopedia, various Glossaries, and Databases are available on the Internet.

Fifth, the most preferred way to obtain their needed materials when failing to find the wanted materials was 'Contact librarian', 'Searching related materials', and 'Request for library purchase'. All of these belong to aggressive solutions. Therefore, it can be said that users have a very high intention for solving any problems within the library. However, students in colleges of Art \& Design, Biomedical \& Health Science, and Global Studies seem reluctant to obtain needed resources within the library. The rate of abandonment was very high. A similar phenomenon occurred in terms of facility use.

Sixth, university K's users are usually satisfied with the loan period, number of borrowed books allowed, librarians' library service, document delivery and interlibrary loan, Homepage configuration and use. However, dissatisfaction about 'opening hours' was significantly higher.

Seventh, the rate of users who don't know whether there is user education was very high, the rate of users who have no experience with user education was quite low. Additionally, most users 
Y. H. Noh et al.
International Journal of Knowledge Content Development \& Technology Vol.1, No.1, $61-79$ (June, 2011)

want the library to provide a library education program. Therefore, the library has to make an effort to develop the user training programs and to promote their user education service.

\section{Acknowledgements}

This work was conducted as a final report for 'seminar in LIS'. The authors would like to thank Patricia Ladd for editing this paper into fluent American English.

\section{References}

Choi, Eun Ju \& Ryoo, Jong-Duk. (2005). An Evaluative Analysis of Service Accessibility on University Library Homepage. Journal of the Korean society for library and information science, 39(3), 245-261.

Gwak, Byeong Hui. (2007). Influential Factors on Users' Satisfaction of University Libraries in Korea. Society for Library and Information Science Journal, (9), 59-95.

Kim, Gyu Hwan \& Nam, Young-Joon. (2007). A Study on Influences of Academic Library Service Quality on the Satisfaction and the Loyalty of Users. Journal of the Korean society for library and information science, 41(2), 135-159.

Kim, Sun Ae. (2008). A Study on the User Satisfaction and Loyalty of University Library Users. Journal of the Korean society for library and information science, 42(3), 281-299.

Lee, Byeong Hee. (2003). A Study on the User Satisfaction of WWW service in University Library, Graduate School Kumoh National Institute of Technology.

Min, Deul Re. (2008). A Study on space betterment of University Library to improve satisfaction. Dept. of Industrial-environment Design Graduate School of Management \& Design Hanyang University.

Nam, Young Joon, Moon, Jung-Hyun, \& Yi, Hyun-Jung. (2009). A Study on User Satisfaction Research about Spacial Composition before and after Remodeling University Library Focused on C University Library. Journal of the Korean Biblia Society for Library and Information Science, 20(4), 205-222.

Oh, Dong geun, \& Kim, Sook-chan. (2006). A Study on the Behaviors and Customer Satisfactions of University Library Users of the Electronic. Journal of the Korean Society for information Management, 23(4), 129-146.

Oh, Dong geun \& Park, Sang-Hoo. (2007). Customer Satisfaction and Loyalty of Academic Library Users Based on Their Perceptions of Library Service Quality. Journal of Information Management, 38(2), 105-126.

Paik, Hang Ki. (2001). The Analyses of Customer Satisfaction Index on University Library Service. Journal of the Korean Biblia Society for Library and Information Science, 12(1), 43-64.

Yu, A Reum. (2010). Customer Satisfaction Survey and Diagnostics Research in the Academic Library. Department of Library and Information Science Graduate School Chonnam National University. 